Article

\title{
Effects of Organic Fertilizer Mixed with Food Waste Dry Powder on the Growth of Chinese Cabbage Seedlings
}

\author{
Sang-Mo Kang ${ }^{1}$, Shifa Shaffique ${ }^{1}$, Lee-Rang Kim ${ }^{1}$, Eun-Hae Kwon ${ }^{1}$, Seong-Heon Kim ${ }^{2}$, Yun-Hae Lee ${ }^{2}$, \\ Kalsoom Kalsoom ${ }^{1}$, Muhammad Aaqil Khan ${ }^{1}$ (D) and In-Jung Lee ${ }^{1, *}$ \\ 1 Department of Applied Biosciences, Kyungpook National University, Daegu 41566, Korea; \\ sangmo@knu.ac.kr (S.-M.K.); shifa.shafiquee@gmail.com (S.S.); pwpw102@knu.ac.kr (L.-R.K.); \\ rnjsdmsgo10@knu.ac.kr (E.-H.K.); kalsoom_bacha@yahoo.com (K.K.); aqil_bacha@yahoo.com (M.A.K.) \\ 2 Development Administration, National Institute of Agricultural Science, Rural, Wanju 55365, Korea; \\ ksh4054@korea.kr (S.-H.K.); mushlee87@korea.kr (Y.-H.L.) \\ * Correspondence: ijlee@knu.ac.kr
}

\section{check for} updates

Citation: Kang, S.-M.; Shaffique, S.; Kim, L.-R.; Kwon, E.-H.; Kim, S.-H.; Lee, Y.-H.; Kalsoom, K.; Aaqil Khan, M.; Lee, I.-J. Effects of Organic Fertilizer Mixed with Food Waste Dry Powder on the Growth of Chinese Cabbage Seedlings. Environments 2021, 8, 86. https://doi.org/10.3390/ environments 8080086

Academic Editor: Helvi

Heinonen-Tanski

Received: 19 July 2021

Accepted: 20 August 2021

Published: 23 August 2021

Publisher's Note: MDPI stays neutral with regard to jurisdictional claims in published maps and institutional affiliations.

Copyright: (c) 2021 by the authors. Licensee MDPI, Basel, Switzerland. This article is an open access article distributed under the terms and conditions of the Creative Commons Attribution (CC BY) license (https:/ / creativecommons.org/licenses/by/ $4.0 /)$.

\begin{abstract}
Food waste is a common global threat to the environment, agriculture, and society. In the present study, we used 30\% food waste, mixed with $70 \%$ bio-fertilizers, and evaluated their ability to affect the growth of Chinese cabbage. The experiment was conducted using different concentrations of food waste to investigate their effect on Chinese cabbage growth, chlorophyll content, and mineral content. Leaf length, root length, and fresh and dry weight were significantly increased in plants treated with control fertilizer (CF) and fertilizer mixed with food waste (MF). However, high concentrations of food waste decreased the growth and biomass of Chinese cabbage due to salt content. Furthermore, higher chlorophyll content, transpiration efficiency, and photosynthetic rate were observed in CF- and MF-treated plants, while higher chlorophyll fluorescence was observed in the MF $\times 2$ and MF $\times 6$ treatments. Inductively coupled plasm mass spectrometry (ICP-MS) results showed an increase in potassium $(\mathrm{K})$, calcium $(\mathrm{Ca})$, phosphorous $(\mathrm{P})$, and magnesium $(\mathrm{Mg})$ contents in the MF and MF $\times 2$ treatments, while higher sodium (Na) content was observed in the $\mathrm{MF} \times 4$ and $\mathrm{MF} \times 6$ treatments due to the high salt content found in food waste. The analysis of abscisic acid (ABA) showed that increasing amounts of food waste increase the endogenous $\mathrm{ABA}$ content, compromising the survival of plants. In conclusion, optimal amounts of food waste-up to MF and MF $\times 2$-increase plant growth and provide an ecofriendly approach to be employed in the agriculture production system.
\end{abstract}

Keywords: Brassica rapa; food waste; organic fertilizer; mineral content; abscisic acid

\section{Introduction}

It is estimated that about one-third to one-quarter of food is wasted. Food waste is also defined as food loss or unconsumed food [1], and it represents the portion of food that is not eaten by anyone [1]. There are various causes of food waste, which may occur at any point of the food chain system, for example during production, processing, distribution, consumption, or at the retail stage. It is estimated that $30-40 \%$ of food is wasted within the food chain [2,3]. Kumar et al. [4] reported that $42 \%$ of waste derives from households, 39\% from food industries, and 5\% occurs during distribution. In order to achieve development goals for a sustainable environment, it is necessary to minimize these quantities. Food waste has a worse effect on the environment and agriculture industry because compositing is not carried out properly [5]. Globally, 1.3 billion tons of food is wasted every year [6], an amount that is equivalent to more than half of the world's annual cereal crop production (2.3 billion tons). Approximately 19 million tons of food waste is reported annually in Japan [7], 16.5 million tons in Taiwan, [8] and 4.3 million tons in Korea [9]. According to the World Economic Forum, in South Korea 95\% of the food waste is recycled in the effort to become a zero waste society $[10,11]$. 
Various strategies can be adopted to minimize wastage [12,13]. Nowadays, the biggest challenges in food waste recovery are animal feeding, reducing the volume of surplus food generation, combating world hunger, providing food waste to rendering industries, and using it for soil amendments or incineration. In recent years, anaerobic digestion (AD) technology for FW resource treatment has attracted considerable attention due to its advantages, as it allows for the obtaining of clean energy and low carbon emissions, and can be used in fertilization programs [14,15]. After the AD processes, the biogas obtained can be upgraded to bio-methane, which is considered an attractive renewable energy, as it is generally used as fuel in the transport sector, or is injected into gas grids, saving tons of $\mathrm{CO}_{2}$-equivalent emissions [14,15]. On the other hand, $\mathrm{AD}$ technology allows for the recycling of nutrients when digestates are applied on agricultural lands, either used as food waste powder directly or mixed with other fertilizers $[14,16]$. For instance, anaerobic digestion for biogas production results in large amounts of liquid digestate, which contains high amounts of nutrients, such as nitrogen, potassium, and phosphorus, as well as micronutrients in plant-available forms [17]. The long-term application of food waste organic fertilizer was shown to improve soil quality, stimulate crop yields, and even have a positive influence on the growth of soil bacteria [17]. Furthermore, food waste can be used as organic fertilizer by compositing natural biological degradation processes $[2,18,19]$. In accordance with the establishment of standards for fertilization processes and amendments to the designation notice, dry waste powder can be used as raw material for organic fertilizers [20,21]. In this case, it must include the standard values of less than $2 \%$ salt, less than $15 \%$ moisture, and less than $30 \%$ of all raw materials [20,22]. Soil salinity is a major abiotic stress that limits plant growth and development by affecting various physiological and biochemical processes. Previous reports have shown that there are many effective ways of improving salt-affected lands, such as water leaching, phytoremediation, and chemical remediation [23]. In particular, the remediation of salt affected soils through chemical agents includes the use of gypsum, organic matter (such as farmyard manure), green manure, or organic food waste [24]. It was also reported that the application of food waste improves the physical, chemical, and biological properties of soil and enhances plant growth and development in various crops such as rice [23], tomato [25], pakchoi [26], and common bean [27].

As it contains salt (and salinity is the biggest obstacle to food waste fertilization), food waste cannot be used directly as fertilizer, and therefore a method that includes mixed fertilization is being proposed as an alternative [22,28]. It is urgent to prepare a plan to effectively utilize food waste as raw material for fertilizers. This research contributes to the development of technology aimed at improving the stability and homogenization of dry powder to be used as a substitute for mixed organic fertilizers $[29,30]$. When food waste is used as raw material for fertilization, various problems-such as excessive salt content, mixing of impurities, and odors-arise [31-33]. Therefore, there is an urgent need to ensure stability and verify the procedures that are essential for safe fertilization processes. In present study, food waste was mixed with organic fertilizer in dry powder form, and its effects on Chinese cabbage seedlings and on the soil environment were analyzed [34,35]. Furthermore, the combined effect of food waste and organic fertilizer on the growth (shoot/root), biomass (fresh/dry weight), and chlorophyll content were also investigated, together with the effect on phytohormonal regulation and content of minerals, such as $\mathrm{N}, \mathrm{P}$, and $\mathrm{K}$.

\section{Materials and Methods}

\subsection{Physicochemical Properties of Soil}

For the analysis of physicochemical properties, we collected soil samples and sieved them to remove impurities. The soil was air dried under normal temperature and sieved through a $2 \mathrm{~mm}$ mesh for further analysis. A quantity of $10 \mathrm{~g}$ of dry soil was mixed with $50 \mathrm{~mL}$ of water (1:5) by vortexing every $10 \mathrm{~min}$ for $1 \mathrm{~min}$. After $1 \mathrm{~h}$, the $\mathrm{pH}$ and electrical conductivity were measured through a $\mathrm{pH}$ meter and EC meter, respectively. Subsequently, 
organic matter was quantified using the Mebius method. A quantity of $0.1-0.5$ air-dried soil $(0.5 \mathrm{~mm})$ was mixed in $10 \mathrm{~mL}$ of $0.4 \mathrm{~N}$ dichromate solution, and $20 \mathrm{~mL}$ of concentrated sulfuric acid was added to a $250 \mathrm{~mL}$ Erlenmeyer flask and heated on an electric plate at $100{ }^{\circ} \mathrm{C}$ for $5 \mathrm{~min}$. After cooling, $200 \mathrm{~mL}$ of distilled water, $10 \mathrm{~mL}$ of concentrated phosphoric acid, and $1 \mathrm{~mL}$ of diphenylamine (16\%) were added [36].

\subsection{Measurement of Available Phosphorous, Nitrate, and Cation Exchange Capacity}

For the analysis of phosphorous content, we used the molybdenum blue method with 1-amino-2-naphtol-4-sulfanic acid, on the basis of the leaching method described in detail by Lancaster $[37,38]$. In this method, the modified molybdenum is used to determine the quantity of enzymatically hydrolyzable phosphorus in the soil. 1-Amino-2-naphtol4-sulfanic acid by Lancaster leaching method was followed for available phosphorus estimation. For the analysis of nitrogen content, the method of Calazans et al. [39] was adopted. The $\mathrm{NH}_{4}{ }^{+}$adsorbed on soil particles was replaced with potassium chloride solution, alkalized with magnesium oxide and titrated to measure ammonia nitrogen. Then, Devarda's alloy was added to convert $\mathrm{NO}_{3}{ }^{-}$to $\mathrm{NH}_{4}{ }^{+}$for distillation titration, and nitrate nitrogen was measured. A quantity of $10 \mathrm{~g}$ of air-dried soil $(2 \mathrm{~mm})$ was mixed with $0.1 \mathrm{~g}$ of a mixture containing sulfate-copper sulfate and selenium (10:10:1) —and $3 \mathrm{~mL}$ of concentrated sulfuric acid in a $100 \mathrm{~mL}$ polyethylene Erlenmeyer flask; then, the contents were shaken for $30 \mathrm{~min}$. The mixture inside the glass tube was digested in a sealed vial and was heated until it turned white. Toward the end of the digestion process, $10 \mathrm{~mL}$ of distilled water was added, and the extract was distilled in the presence of sodium hydroxide $(13 \mathrm{~mol} / \mathrm{L})$ in a Kjeldahl distiller. The extract was placed into a boric acid solution until a total of $50 \mathrm{~mL}$ of condensate in the flasks was obtained. The distillate samples were titrated with $0.01 \mathrm{~N} \mathrm{H}_{2} \mathrm{SO}_{4}$, and the total nitrogen content in soil samples was calculated.

For the analysis of cation exchange capacity, $10 \mathrm{~g}$ of soil dried at $40{ }^{\circ} \mathrm{C}$ was weighted and put in centrifuged tubes, and $50 \mathrm{~mL}$ of $1 \mathrm{~N}$ NH4OAc $(\mathrm{pH} 7)$ solution was added. The tubes were then kept in a shaking incubator for $3 \mathrm{~h}$ at $140 \mathrm{rpm}$ and centrifuged at $600 \mathrm{rpm}$ for $10 \mathrm{~min}$. A $5.5 \mathrm{~cm}$ Buchner funnel with retentive filter paper was fit, the paper was moistened, and the soil extract was transferred. The decanted liquid was collected in a $100 \mathrm{~mL}$ volumetric flask and was added with $1 \mathrm{~N}$ NH4OAc solution until reaching a volume of $100 \mathrm{~mL}$. The exchangeable bases $\left(\mathrm{K}, \mathrm{Na}, \mathrm{Mg}_{2}\right.$, and $\left.\mathrm{Ca}_{2}\right)$ were determined through the ICP measurement method.

\section{Experimental Set Up}

The Chinese cabbage needed for the experiment was purchased from Seoul-baechu, (Danong, Gyeonggi province, South Korea), and seedlings were grown for 3 weeks in a 72 Cells Seedling Trays $(11 \times 21.25 \times 1.8$ inches) containing horticultural soil (peat moss (10-15\%), coco peat (45-50\%), zeolite (6-8\%), and perlite (35-40\%), along with $\mathrm{NH}^{+}$ $(\approx 0.09 \mathrm{mg} / \mathrm{g}), \mathrm{NO}_{3}(\approx 0.205 \mathrm{mg} / \mathrm{g}), \mathrm{PO}(\approx 0.35 \mathrm{mg} / \mathrm{g})$, and $\left.\mathrm{KO}(\approx 0.1 \mathrm{mg} / \mathrm{g})\right)$ purchased from (Shinsung Mineral Co., Ltd., Goesan, Korea) [40,41]. The organic fertilizer mixed with food (MF) waste was incorporated into the upper $10 \mathrm{~cm}$ soil layer, and supplemented with various amounts of food waste, on the basis of the experimental design. The pots $(17.0 \times 12.0 \times 13 \mathrm{~cm})$ were labeled properly and divided into six groups $(\mathrm{A})$ NT: not treated control; (B) CF: controlled fertilizers (3.78 g per pot), which were added only with high quality uniform compound fertilizer from a registered company (poweralchandeul, Farmhannong Co., Ltd.,Yeongdeungpo-gu, Seoul, Korea, N-P2O5-K2O: 12-6-6); (C) MF: mixed fertilizer (10.61 g per pot) composed of castor oil cake/rapeseed oil/food waste powder (49:21:30), wherein a sub-group $(\mathrm{MF} \times 2)$ was set up where the quantity of mixed fertilizer was double; (D) the amount of mixed fertilizer was increased four times; and (E) the amount of mixed fertilizer was increased six times. 


\section{Morphological Analysis}

After 4 weeks of growth using organic fertilizers mixed with different concentrations of food waste, growth parameters, namely, root length, shoot length, fresh and dry weight, were measured. Furthermore, a LCpro T portable photosynthetic assay system (ADC Bioscientific Ltd., Herts, England) was used for the quantification of transpiration rate, stomatal conductance, and photosynthetic rate.

\section{Endogenous Abscisic Acid (ABA) Quantification}

For the quantification of endogenous $\mathrm{ABA}$, we used the detailed method by Khan et al. [42,43]. A quantity of $0.3 \mathrm{~g}$ of freeze-dried sample was treated with $30 \mathrm{~mL}$ of extract solution (isopropanol, 95\%, and glacial acetic acid, 10\%), and $100 \mathrm{ng}$ of ABA standard $\left[( \pm)-3,5,5,7,7,7-\mathrm{d}^{6}\right]$ was added. The suspension was filtered, and the filtrate was concentrated using a rotary evaporator. The residue was suspended in $4 \mathrm{~mL}$ of $1 \mathrm{~N} \mathrm{NaOH}$ solution and rinsed three times with methylene chloride $(3 \mathrm{~mL})$ in order to eliminate traces of lipophilic material. After decreasing the $\mathrm{pH}$ of the aqueous phase to 3.5 by adding $6 \mathrm{~N}$ $\mathrm{HCl}$, we extracted it through solvent extraction with ethyl acetate three times. The ethyl acetate extract was then evaporated and the dry residue was re-suspended in phosphate buffer solution ( $\mathrm{pH} 8$ ), which was passed through a polyvinylpolypyrrolidone column. The eluted phosphate buffer solution was once again partitioned three times with EtOAc, after adjusting to $\mathrm{pH} 3.5$ with $6 \mathrm{~N} \mathrm{HCl}$. All three aliquots extracted were pooled and evaporated using the rotary evaporator. Subsequently, the fractions were methylated with diazomethane to detect and quantify ABA using GC-MS/SIM equipment (6890N network gas chromatograph, Agilent Technologies) (Scheme 1). ThermoQuest Crop. (Manchester, UK) software was used to monitor signal ions $(\mathrm{m} / z 1162$ and 190 for Me-ABA, and $\mathrm{m} / \mathrm{z} 166$ and 194 for Me- $\left.\left[{ }_{2} \mathrm{H}^{6}\right]-\mathrm{ABA}\right)$.

\begin{tabular}{cc}
\hline Equipment & Hewlett-Packard 6890, 5973N Mass Selective Detector \\
\hline Column & $\mathrm{HP}-1$ capillary column $(30 \mathrm{~m} \times 0.25 \mathrm{~mm}$ i.d. $0.25 \mu \mathrm{m}$ film thickness $)(\mathrm{J} \& \mathrm{~W}$ Scientific Co., Folsom, CA, USA $)$ \\
Carrier gas & $\mathrm{He}(40 \mathrm{~mL} / \mathrm{min}$.$) ; head pressure of 30 \mathrm{kPa}$ \\
Source temp. & $250{ }^{\circ} \mathrm{C}$ \\
Oven conditions & ABA: $60^{\circ} \mathrm{C}(1 \mathrm{~min}.) 15^{\circ} \mathrm{C} / \mathrm{min} ; 200{ }^{\circ} \mathrm{C}, 5^{\circ} \mathrm{C} / \mathrm{min} ; 250{ }^{\circ} \mathrm{C}, 10^{\circ} \mathrm{C} / \mathrm{min} ; 280^{\circ} \mathrm{C}$ \\
Injector temp. & $200{ }^{\circ} \mathrm{C}$ \\
Ionizing voltage & $70 \mathrm{ev}$ \\
\hline
\end{tabular}

Scheme 1. GC/MS-SIM conditions used for analysis and quantification of the ABA.

\section{ICP Analysis of the Uptake of Different Elements}

For the quantification of different elements absorbed, such as sodium $(\mathrm{Na})$, potassium $(\mathrm{K})$, calcium $(\mathrm{Ca})$, phosphorous $(\mathrm{P})$, and magnesium $(\mathrm{Mg})$, we followed the methods described in Khan et al. [44] and Sahile et al. [45], using $200 \mathrm{mg}$ of freeze-dried powder. All the samples were digested with $5 \mathrm{~mL}$ of $\mathrm{HNO}_{3}$ and $3 \mathrm{~mL}$ of $\mathrm{H}_{2} \mathrm{O}_{2}$ in a microwave oven. Subsequently, 3\% of $\mathrm{HNO}_{3}$ was added to digest the samples and was injected in an inductively coupled plasm mass spectrometry analyzer (Optima 7900DV, Perkin-Elmer, Waltham, MA, USA).

\section{Statistical Analysis}

The results of the current study were performed in a completely randomized design and were subjected to statistical analysis. The experiments were conducted as three parallels, and every replicate included 20 plants. Graphs were generated using Graph Pad Prism software (Version 6.01, San Diego, CA, USA), whereas means with standard error were compared using Duncan's multiple range test (DMRT) in SAS (V9.1, Cary, NC, USA). 


\section{Results and Discussion}

\subsection{Physicochemical Properties of Soil}

It is very important to monitor the physicochemical characteristics of soil because soil is a complex material that consists of various components, such as minerals, moisture, and organic matter [46]. These components greatly influence soil structure, texture, and porosity. Before the experiment, the electrical conductivity; organic matter content; and available phosphorus, nitrogen, calcium, potassium, magnesium, and sodium were analyzed (Table 1). Soil $\mathrm{pH}$ and electrical conductivity were 6.6 and $2.8 \mathrm{dS}$, respectively. Soil pH, whose optimal range is 5-7 for agricultural crops [47], plays a vital role in the regulation of nutrient availability [48], and is an indicator of the overall chemical status of soil [49]. Electrical conductivity is also an important indicator of soil health that affects plant nutrient availability and crop yield [50]. Moreover, soil is a major source of nutrients, and soil nutrient availability is essential in sustaining soil quality and plant productivity [51,52]. The nutrient contents obtained from soil analysis are the following: organic carbon, $20 \mathrm{~g} / \mathrm{kg}$; nitrate nitrogen, $141.8 \mathrm{mg} / \mathrm{kg}$; available phosphorus, $330 \mathrm{mg} / \mathrm{kg}$; $\mathrm{K}, 1.11 \mathrm{mg} / \mathrm{kg} ; \mathrm{Mg}, 3.65 \mathrm{mg} / \mathrm{kg}$; and $\mathrm{Na} 0.6 \mathrm{mg} / \mathrm{kg}$, as shown in Table 1 . Crops plants need 16 essential elements that are vital for their normal growth [53]. The over-application of fertilizers, using water irrigation, can cause a micronutrient imbalance in soil and nutrients available to plants. Among the nutrients, organic matter increases the chemical and physical properties of soil that contribute to plant growth and development [54].

Table 1. Physicochemical properties of the soil used in the experiment.

\begin{tabular}{|c|c|c|c|c|c|c|c|c|}
\hline \multirow{2}{*}{$\mathrm{pH}[1: 5]$} & \multirow{2}{*}{$\begin{array}{c}\text { EC } \\
{[1: 5](d S / m)}\end{array}$} & \multirow{2}{*}{$\begin{array}{l}\text { OM } \\
(\mathrm{g} / \mathrm{kg})\end{array}$} & \multirow{2}{*}{$\begin{array}{l}\mathrm{NO}_{3}-\mathrm{N} \\
(\mathrm{mg} / \mathrm{kg})\end{array}$} & \multirow{2}{*}{$\begin{array}{c}\text { AP } \\
(\mathrm{mg} / \mathrm{kg})\end{array}$} & \multicolumn{4}{|c|}{ Ex. Cation (cmol/kg) } \\
\hline & & & & & K & $\mathrm{Ca}$ & $\mathrm{Mg}$ & $\mathrm{Na}$ \\
\hline 6.6 & 2.8 & 20 & 141.8 & 330 & 1.11 & 11.61 & 3.65 & 0.6 \\
\hline
\end{tabular}

EC: electrical conductivity, AP: available phosphorus, OM: organic matter.

\subsection{Effect of Food Waste on the Growth, Biomass, and Chlorophyll Content of Chinese Cabbage}

Currently, food waste is one of the most urgent challenges facing the environment, society, and the economy because of the devastating effects it produces [55]. Different strategies are employed to manage/recycle wasted food, such as the use as fertilizer, and feeding [30]. However, using food waste as fertilizer presents a problem, namely, salinity stress. The excess sodium concentration of food waste may cause ionic imbalance, as it produces several morphological and physiological changes that inhibit crop growth and development [56-58]. However, optimal doses of food waste have been demonstrated to play a significant role in fertilization, as shown in Tables 2 and 3. In the current experiment, the growth characteristics of Chinese cabbage were investigated. After four weeks, the CF- and MF-treated plants showed an increase in leaf length $(12.6-12.9 \mathrm{~cm})$, root length $(11.8-15.3 \mathrm{~cm})$, fresh weight $(14.7-16.5 \mathrm{~g})$, and dry weight $(3.4-3.9 \mathrm{~g})$ compared to the control NT plants, where the same parameters were lower: leaf length $(11.8 \mathrm{~cm})$, root length $(9.3 \mathrm{~cm})$, fresh weight $(13.4 \mathrm{~g})$, and dry weight $(2.5 \mathrm{~g})$. However, leaf length decreased in the MF $\times 2-, M F \times 4-$, and MF $\times$ 6-treated plants (Table 2). In Table 3, results show that chlorophyll fluorescence, which measures the photosynthetic rate, was higher in the $\mathrm{MF} \times 2$ - and $\mathrm{MF} \times 6$-treated groups than in the other treated groups $(\mathrm{CF}, \mathrm{MF}$, and $\mathrm{MF} \times 4$ ), and ranged between 0.76 and 0.79 , which satisfactorily meets the needs of plants. In contrast, the transpiration rate decreased in the $\mathrm{MF} \times 2$ - and $\mathrm{MF} \times 6$-treated plants (Table 3). The level of stomatal conductance, which measures the water relationships within a plant, decreased to $0.03 \pm 0.0 \mathrm{~mol} / \mathrm{m}^{2}$ in the treated groups (except for $\mathrm{CF}$ ), showing that the treated plants are not able to withstand drought or salinity stress. Similar results were also observed for the photosynthetic rates between treated and non-treated Chinese cabbage plants (Table 3). 
Table 2. Growth characteristics of Chinese cabbage.

\begin{tabular}{ccccccc}
\hline Fertilizations & NT & CF & MF & MF $\times \mathbf{2}$ & MF $\times \mathbf{4}$ & MF $\times \mathbf{6}$ \\
\hline Leaf Length $(\mathrm{cm})$ & $11.8 \pm 0.87 \mathrm{ab}$ & $12.9 \pm 2.19 \mathrm{a}$ & $12.6 \pm 0.95 \mathrm{a}$ & $11.7 \pm 0.76 \mathrm{ab}$ & $10.9 \pm 0.32 \mathrm{ab}$ & $8.2 \pm 0.46 \mathrm{~b}$ \\
\hline Root Length $(\mathrm{cm})$ & $9.3 \pm 0.77 \mathrm{a}$ & $11.8 \pm 2.20 \mathrm{a}$ & $15.3 \pm 7.98 \mathrm{a}$ & $11.1 \pm 0.13 \mathrm{a}$ & $11.7 \pm 2.39 \mathrm{a}$ & $9.8 \pm 1.07 \mathrm{a}$ \\
\hline Fresh Weight $(\mathrm{g})$ & $13.4 \pm 4.33 \mathrm{ab}$ & $14.7 \pm 4.62 \mathrm{a}$ & $16.5 \pm 3.69 \mathrm{a}$ & $9.5 \pm 1.39 \mathrm{ab}$ & $7.9 \pm 1.81 \mathrm{ab}$ & $3.3 \pm 0.29 \mathrm{~b}$ \\
\hline Dry Weight $(\mathrm{g})$ & $2.5 \pm 0.48 \mathrm{bc}$ & $3.9 \pm 0.61 \mathrm{a}$ & $3.4 \pm 0.13 \mathrm{ab}$ & $2.6 \pm 0.39 \mathrm{bc}$ & $2.0 \pm 0.35 \mathrm{~cd}$ & $1.2 \pm 0.29 \mathrm{~d}$ \\
\hline
\end{tabular}

NT: not treated; CF: controlled fertilizer; MF: castor oilcakes 49, rapeseed oil cake 21, food waste powder 30; MF $\times 2$ (mixed expeller cake and food waste powder); MF $\times 4$ (mixed expeller cake and food waste powder); MF $\times 6$ (mixed expeller cake and food waste powder). Each value represents mean $+\mathrm{SD}$ of three replicates. Values with different letters in rows are significantly different from each other, as evaluated by DMRT.

Table 3. Photosynthetic characteristics of Chinese cabbage.

\begin{tabular}{|c|c|c|c|c|c|c|}
\hline Fertilizations & NT & $\mathrm{CF}$ & MF & $\mathrm{MF} \times 2$ & $\mathrm{MF} \times 4$ & $\mathrm{MF} \times 6$ \\
\hline $\begin{array}{l}\text { Chlorophyll Contents } \\
\mathrm{mg} / \mathrm{m}^{2}\end{array}$ & $487.7 \pm 27.28 b$ & $521.7 \pm 13.13 \mathrm{a}$ & $477.3 \pm 34.89 \mathrm{~b}$ & $464.3 \pm 38.52 b$ & $439.3 \pm 40.91 \mathrm{c}$ & $427.7 \pm 37.53 c$ \\
\hline $\begin{array}{l}\text { Chlorophyll Fluorescence } \\
\text { (Fv/Fm) }\end{array}$ & $0.80 \pm 0.011 \mathrm{a}$ & $0.79 \pm 0.023 \mathrm{a}$ & $0.79 \pm 0.010 \mathrm{a}$ & $0.81 \pm 0.039 \mathrm{a}$ & $0.76 \pm 0.038 \mathrm{a}$ & $0.82 \pm 0.023 \mathrm{a}$ \\
\hline $\begin{array}{l}\text { Transpiration Efficiencies } \\
\left(\mathrm{mmol} / \mathrm{m}^{2}\right)\end{array}$ & $2.0 \pm 0.35 \mathrm{ab}$ & $2.3 \pm 0.31 \mathrm{a}$ & $2.0 \pm 0.37 \mathrm{ab}$ & $1.6 \pm 0.27 \mathrm{ab}$ & $1.5 \pm 0.24 \mathrm{ab}$ & $1.3 \pm 0.00 \mathrm{~b}$ \\
\hline $\begin{array}{l}\text { Stomatal Conductance } \\
\left(\mathrm{mol} / \mathrm{m}^{2} \mathrm{~s}\right)\end{array}$ & $0.08 \pm 0.020 \mathrm{a}$ & $0.09 \pm 0.015 \mathrm{a}$ & $0.07 \pm 0.013 \mathrm{ab}$ & $0.05 \pm 0.007 \mathrm{ab}$ & $0.04 \pm 0.007 \mathrm{~b}$ & $0.03 \pm 0.000 \mathrm{~b}$ \\
\hline $\begin{array}{l}\text { Photosynthetic Rate } \\
\left(\mu \mathrm{mol} / \mathrm{m}^{2} \mathrm{~s}\right)\end{array}$ & $2.8 \pm 0.04 \mathrm{a}$ & $2.9 \pm 1.14 \mathrm{a}$ & $2.3 \pm 0.81 \mathrm{ab}$ & $2.0 \pm 0.98 \mathrm{ab}$ & $1.2 \pm 0.33 \mathrm{ab}$ & $0.2 \pm 0.16 b$ \\
\hline
\end{tabular}

Each value represents mean + SD of three replicates. Values with different letters in rows are significantly different from each other, as evaluated by DMRT.

\subsection{Effect of Food Waste on $A B A$ and Mineral Uptake in Chinese Cabbage}

Phyto-hormones, especially ABA, play a crucial role in plant responses to various environmental conditions [59,60]. In the present study, higher ABA contents were observed in the MF $\times 2$ - and MF $\times 4$-treated plants than in NT and CF-treated plants (Figure 1). In contrast, a decrease in $\mathrm{ABA}$ content was observed in $\mathrm{MF} \times 6$-treated plants, possibly due to an overdose of food waste that led to the death of plants, a hypothesis that is also supported by the observed growth parameters. The increase in ABA content in MF $\times 2$ and MF $\times 4$-treated plants might have been due to the double and quadruple increase in the salt content of food waste. This result also supports the observation [61-63] that high salinity in maize, rice, and soybean enhances ABA contents. Furthermore, this increase in ABA content was also correlated with the ICP analysis of Na content in Chinese cabbage plants, which showed a higher Na content in MF $\times 2-\mathrm{MF} \times 6$-treated plants than in NT and CF-treated plants. This increase was due to the salt content present in food waste powder. Moreover, $\mathrm{Na}$ content also affected the uptake of $\mathrm{K}, \mathrm{Mg}$, $\mathrm{Ca}$, and $\mathrm{P}$ mineral ions in Chinese cabbage (Table 4). The concentrations of potassium, calcium, phosphorus, and magnesium were higher in the MF and MF $\times 2$ groups than in the MF $\times 4$ and $\mathrm{MF} \times 6$ groups. The amount of sodium increases with increasing concentrations of food waste (which is alarming) and induces salinity stress. Excess sodium ions cause ionic imbalance, as they compete with potassium ions, possibly resulting in necrosis and chlorosis [63]. Higher contents of $\mathrm{K}$ were observed in the MF- and MF $\times 2$-treated plants, with significant effects on plant growth and photosynthetic rates. Previous studies showed that K plays a vital role in photosynthesis and in the translocation of nutrients in plants; it is considered a major nutrient, essential for plant growth and development [64]. Similarly, higher Mg concentrations also play an essential role in plant photosynthesis and growth, as this element is the central atom amid four nitrogen atoms in the chlorophyll molecule [65]. Another micronutrient is calcium $(\mathrm{Ca})$, which provides structural support to the cell wall and acts as a secondary messenger when plants are stressed [66]. 


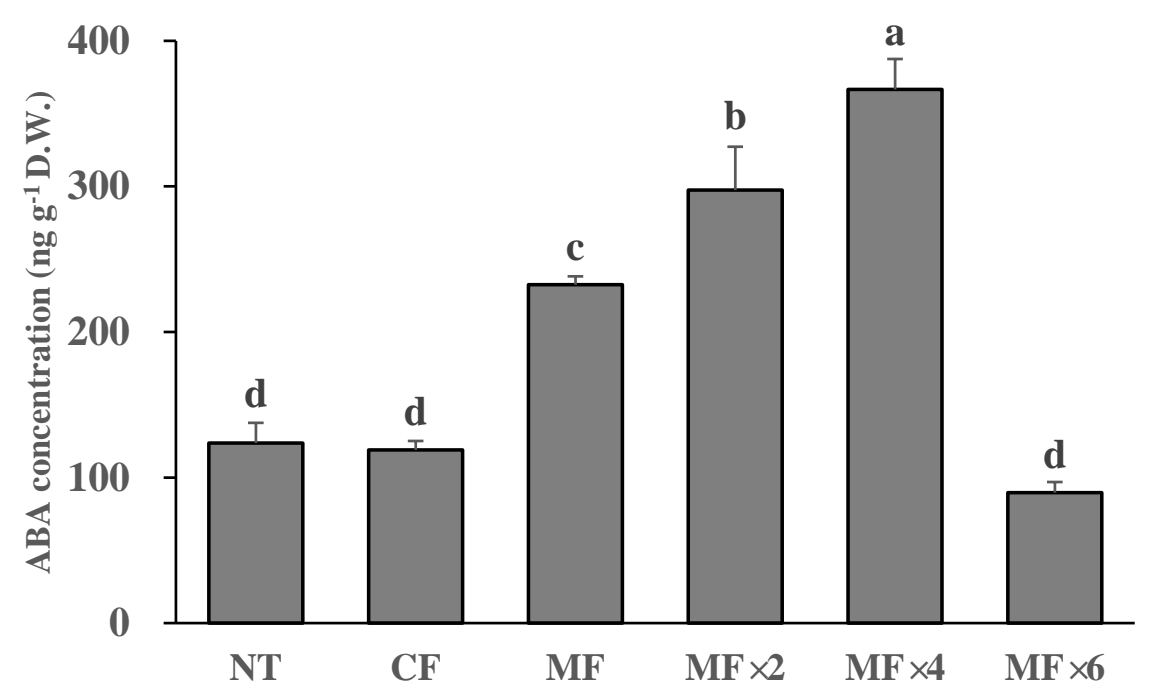

Figure 1. Endogenous abscisic acid quantification in Chinese cabbage. Each data point is the mean of at least three replicates. Error bars represent standard errors. The bars presented with different letters are significantly different from each other as evaluated by DMRT.

Table 4. ICP analysis results for Chinese cabbage (ppm).

\begin{tabular}{ccccccc}
\hline Fertilizations & NT & CF & MF & MF $\times \mathbf{2}$ & MF $\times \mathbf{6}$ \\
\hline $\mathrm{K}$ & $39,299.7 \pm 1293.15 \mathrm{bc}$ & $35,599.1 \pm 1196.16 \mathrm{~cd}$ & $41,376.2 \pm 1799.51 \mathrm{~b}$ & $45,963.0 \pm 453.94 \mathrm{a}$ & $34,778.5 \pm 255.90 \mathrm{~d}$ & $33,702.2 \pm 1560.46 \mathrm{~d}$ \\
\hline $\mathrm{Ca}$ & $26,330.3 \pm 313.83 \mathrm{c}$ & $24,458.4 \pm 46.37 \mathrm{e}$ & $27,073.3 \pm 235.13 \mathrm{~b}$ & $28,049.7 \pm 72.54 \mathrm{a}$ & $25,568.1 \pm 144.60 \mathrm{~d}$ & $25,286.8 \pm 70.72 \mathrm{~d}$ \\
\hline $\mathrm{P}$ & $5196.9 \pm 32.98 \mathrm{a}$ & $5261.6 \pm 58.48 \mathrm{a}$ & $5152.1 \pm 32.12 \mathrm{a}$ & $5244.7 \pm 36.28 \mathrm{a}$ & $4894.4 \pm 104.39 \mathrm{~b}$ & $4661.9 \pm 25.51 \mathrm{c}$ \\
\hline $\mathrm{Mg}$ & $5597.6 \pm 30.18 \mathrm{~d}$ & $5641.4 \pm 17.84 \mathrm{~cd}$ & $5768.0 \pm 3.47 \mathrm{bcd}$ & $6046.8 \pm 20.85 \mathrm{a}$ & $5826.1 \pm 132.71 \mathrm{bc}$ & $5892.6 \pm 2.15 \mathrm{ab}$ \\
\hline $\mathrm{Na}$ & $5368.8 \pm 213.93 \mathrm{bc}$ & $4543.9 \pm 240.26 \mathrm{c}$ & $5165.0 \pm 343.59 \mathrm{bc}$ & $5466.0 \pm 102.77 \mathrm{bc}$ & $6322.9 \pm 179.15 \mathrm{~b}$ & $8739.3 \pm 605.16 \mathrm{a}$ \\
\hline
\end{tabular}

Each value represents the mean + SD of three replicates. Values with different letters in rows are significantly different from each other, as evaluated by DMRT.

In summary, the combined application of organic and mineral fertilizers is the best approach to achieve multiple aims in terms of high yields, low-cost farming, and minimal negative environmental impacts. The good performance of this combination, together with the reduced expenses for mineral fertilizers, can encourage farmers to accept the use of organic fertilizers. Nabel et al. [67] reported that organic fertilization with digestates had a positive influence on soil properties (e.g., increased soil respiration and enhanced water-holding capacity), particularly in marginal sites. Organic fertilization via food waste would improve crop yields and soil fertility and should be considered as an effective strategy to manage compostable wastes. Mu et al. [68] reported the impacts of different compost treatments rates $(10 \%, 30 \%, 50 \%$, and $70 \% \mathrm{v} / \mathrm{v})$, and synthetic fertilizers showed a positive effect on soil fertility, plant yield, and plant nutrient content in arugula and radish plants. Similarly, Dlamlnl et al. [69] also investigated the effect of organic food waste on soil conditions and on the yield of vegetables, and concluded that food waste fertilizers can be used as an alternative to synthetic fertilizers to increase crop yield and improve the physical properties of soil. At the same time, the negative impact of synthetic fertilizers on the environment would be reduced, as well as the impact of disposing of vegetable food waste in landfills.

\section{Conclusions}

In this study, Chinese cabbage was treated with different concentrations of food waste along with a $70 \%$ fertilizer component. An increase in Chinese cabbage growth parameters was observed up to the MF $\times 2$ treatment. However, when the dose of food waste was further increased to four- and sixfold concentrations, plants showed inhibitory growth regulation. We demonstrated that the fertilization of seedlings with food waste within the 
optimal MF to $\mathrm{MF} \times 2$ range provides a valuable, ecofriendly, and low-cost biotechnological approach for the improvement of sustainable crop production. Further on-field studies are needed to observe the effect of food waste on the soil micro- and macronutrient composition, as well as on the fertility rate in the long term. In addition, as the release of $\mathrm{Na}^{+}$increases soil salinity, it is necessary to determine the proper application doses of these organic by-products in order to avoid negative impacts on soil, the environment, and human health. Moreover, different strategies are needed to avoid the negative impact of sodium on the growth of crops, as food waste contains more salt.

Author Contributions: S.-M.K. and L.-R.K. conducted the experiments. E.-H.K. and K.K. conducted hormonal, and ICP analyses. S.-H.K. and Y.-H.L. help in resources, M.A.K. and S.S. wrote the manuscript and answered reviewer comments. I.-J.L. designed, supervised, and financed the research. All authors have read and agreed to the published version of the manuscript.

Funding: This study was supported by the Agenda Program (Project No. PJ015163032021) Rural Development Administration, Republic of Korea.

Institutional Review Board Statement: Not applicable.

Informed Consent Statement: Not applicable.

Data Availability Statement: Not applicable.

Conflicts of Interest: The authors declare no conflict of interest.

\section{References}

1. Bratovcic, A.; Zohorović, M.; Odobasic, A.; Šestan, I. Efficiency of food waste as an organic fertilizer. Int. J. Eng. Sci. Res. Technol. 2018, 7, 527-530. [CrossRef]

2. Papargyropoulou, E.; Lozano, R.; Steinberger, J.K.; Wright, N.; bin Ujang, Z. The food waste hierarchy as a framework for the management of food surplus and food waste. J. Clean. Prod. 2014, 76, 106-115. [CrossRef]

3. Scherhaufer, S.; Moates, G.; Hartikainen, H.; Wald, K.; Obersteiner, G. Environmental impacts food waste in Europe. Waste Manag. 2018, 77, 98-113. [CrossRef]

4. Kumar, K.; Yadav, A.N.; Kumar, V.; Vyas, P.; Dhaliwal, H.S. Food waste: A potential bioresource for extraction of nutraceuticals and bioactive compounds. Bioresour. Bioprocess. 2017, 4, 18. [CrossRef]

5. Girotto, F.; Alibardi, L.; Cossu, R. Food waste generation and industrial uses: A review. Waste Manag. 2015, 45, 32-41. [CrossRef]

6. Paritosh, K.; Kushwaha, S.K.; Yadav, M.; Pareek, N.; Chawade, A.; Vivekanand, V. Food Waste to Energy: An Overview of Sustainable Approaches for Food Waste Management and Nutrient Recycling. BioMed Res. Int. 2017, 2017, 1-19. [CrossRef]

7. Melikoglu, M.; Lin, C.S.K.; Webb, C. Analysing global food waste problem: Pinpointing the facts and estimating the energy content. Cent. Eur. J. Eng. 2013, 3, 157-164. [CrossRef]

8. Mao, I.-F.; Tsai, C.-J.; Shen, S.-H.; Lin, T.-F.; Chen, W.-K.; Chen, M.-L. Critical components of odors in evaluating the performance of food waste composting plants. Sci. Total Environ. 2006, 370, 323-329. [CrossRef]

9. Kim, J.-D.; Park, J.-S.; In, B.-H.; Kim, D.; Namkoong, W. Evaluation of pilot-scale in-vessel composting for food waste treatment. J. Hazard. Mater. 2008, 154, 272-277. [CrossRef] [PubMed]

10. Broom, D. South Korea Once Recycled 2\% of Its Food Waste. Now It Recycles 95\%. In Proceedings of the World Economic Forum. Available online: https://www.weforum.org/agenda/2019/04/south-korea-recycling-food-waste/ (accessed on 12 April 2019).

11. Shvetsova, O.A.; Lee, J.H. Minimizing the environmental impact of industrial production: Evidence from south korean waste treatment investment projects. Appl. Sci. 2020, 10, 3489. [CrossRef]

12. Kiran, E.U.; Trzcinski, A.P.; Ng, W.J.; Liu, Y. Bioconversion of food waste to energy: A review. Fuel 2014, 134, 389-399. [CrossRef]

13. Stenmarck, Â.; Jensen, C.; Quested, T.; Moates, G.; Buksti, M.; Cseh, B.; Juul, S.; Parry, A.; Politano, A.; Redlingshofer, B. Estimates of European Food Waste Levels; IVL Swedish Environmental Research Institute: Stockholm, Sweden, 2016.

14. Iglesias, R.; Muñoz, R.; Polanco, M.; Díaz, I.; Susmozas, A.; Moreno, A.D.; Guirado, M.; Carreras, N.; Ballesteros, M. Biogas from Anaerobic Digestion as an Energy Vector: Current Upgrading Development. Energies 2021, 14, 2742. [CrossRef]

15. David, A.; Govil, T.; Tripathi, A.K.; McGeary, J.; Farrar, K.; Sani, R.K. Thermophilic Anaerobic Digestion: Enhanced and Sustainable Methane Production from Co-Digestion of Food and Lignocellulosic Wastes. Energies 2018, 11, 2058. [CrossRef]

16. Pilarska, A.A.; Pilarski, K.; Wolna-Maruwka, A.; Boniecki, P.; Zaborowicz, M. Use of Confectionery Waste in Biogas Production by the Anaerobic Digestion Process. Molecules 2019, 24, 37. [CrossRef] [PubMed]

17. Dragicevic, I.; Sogn, T.A.; Eich-Greatorex, S. Recycling of Biogas Digestates in Crop Production-Soil and Plant Trace Metal Content and Variability. Front. Sustain. Food Syst. 2018, 2, 2. [CrossRef]

18. Schneider, F. Review of food waste prevention on an international level. In Proceedings of the Institution of Civil Engineers-Waste and Resource Management; ICE Publishing: London, UK, 2013; pp. 187-203.

19. Evans, D.M. Food Waste: Home Consumption, Material Culture and Everyday Life; Bloomsbury Publishing: London, UK, 2014. 
20. Appelhof, M.; Olszewski, J. Worms Eat. My Garbage: How to Set Up and Maintain a Worm Composting System: Compost Food Waste, Produce Fertilizer for Houseplants and Garden, and Educate Your Kids and Family; Storey Publishing: Adams, MA, USA, 2017.

21. Choi, Y.-C.; Choi, J.-Y.; Kim, J.-G.; Kim, M.-S.; Kim, W.-T.; Park, K.-H.; Bae, S.-W.; Jeong, G.-S. Potential usage of food waste as a natural fertilizer after digestion by Hermetia illucens (Diptera: Stratiomyidae). Int. J. Ind. Entomol. 2009, 19, 171-174.

22. Owamah, H.I.; Dahunsi, S.O.; Oranusi, U.S.; Alfa, M.I. Fertilizer and sanitary quality of digestate biofertilizer from the co-digestion of food waste and human excreta. Waste Manag. 2014, 34, 747-752. [CrossRef]

23. Cha-um, S.; Kirdmanee, C. Remediation of salt-affected soil by the addition of organic matter: An investigation into improving glutinous rice productivity. Sci. Agric. 2011, 68, 406-410. [CrossRef]

24. Tejada, M.; Garcia, C.; Gonzalez, J.L.; Hernandez, M.T. Use of organic amendment as a strategy for saline soil remediation: Influence on the physical, chemical and biological properties of soil. Soil Biol. Biochem. 2006, 38, 1413-1421. [CrossRef]

25. Tartoura, K.A.H.; Youssef, S.A.; Tartoura, E.-S.A.A. Compost alleviates the negative effects of salinity via up-regulation of antioxidants in Solanum lycopersicum L. plants. Plant. Growth Regul. 2014, 74, 299-310. [CrossRef]

26. Zheng, S.; Jiang, J.; He, M.; Zou, S.; Wang, C. Effect of kelp waste extracts on the growth and development of Pakchoi (Brassica chinensis L.). Sci. Rep. 2016, 6, 1-9. [CrossRef]

27. Rady, M.M.; Semida, W.M.; Hemida, K.A.; Abdelhamid, M.T. The effect of compost on growth and yield of Phaseolus vulgaris plants grown under saline soil. Int. J. Recycl. Org. Waste Agric. 2016, 5, 311-321. [CrossRef]

28. Diacono, M.; Montemurro, F. Effectiveness of organic wastes as fertilizers and amendments in salt-affected soils. Agriculture 2015, 5, 221-230. [CrossRef]

29. Damiani, M.; Pastorello, T.; Carlesso, A.; Tesser, S.; Semenzin, E. Quantifying environmental implications of surplus food redistribution to reduce food waste. J. Clean. Prod. 2021, 289, 125813. [CrossRef]

30. Barrera, E.L.; Hertel, T. Global food waste across the income spectrum: Implications for food prices, production and resource use. Food Policy 2021, 98, 101874. [CrossRef]

31. Chen, Z.; Li, Y.; Peng, Y.; Ye, C.; Zhang, S. Effects of antibiotics on hydrolase activity and structure of microbial community during aerobic co-composting of food waste with sewage sludge. Bioresour. Technol. 2021, 321, 124506. [CrossRef] [PubMed]

32. Andraskar, J.; Yadav, S.; Kapley, A. Challenges and Control Strategies of Odor Emission from Composting Operation. Appl. Biochem. Biotechnol. 2021, 193, 2331-2356. [CrossRef]

33. Jin, C.; Sun, S.; Yang, D.; Sheng, W.; Ma, Y.; He, W.; Li, G. Anaerobic digestion: An alternative resource treatment option for food waste in China. Sci. Total. Environ. 2021, 779, 146397. [CrossRef] [PubMed]

34. Kaur, G.J.; Orsat, V.; Singh, A. Challenges and potential solutions to utilization of carrot rejects and waste in food processing. Br. Food J. 2021, 123, 2036-2048. [CrossRef]

35. Yeo, J.; Oh, J.-i.; Cheung, H.H.L.; Lee, P.K.; An, A.K. Smart Food Waste Recycling Bin (S-FRB) to turn food waste into green energy resources. J. Environ. Manag. 2019, 234, 290-296. [CrossRef]

36. Mebius, L.J. A rapid method for the determination of organic carbon in soil. Anal. Chim. Acta 1960, 22, 120-124. [CrossRef]

37. Yang, W.-S.; Kang, S.-S.; Kim, K.-I.; Hong, S.-D. Comparison of determination methods for available-P in soil of plastic film house. Korean J. Soil Sci. Fertil. 2006, 39, 163-172.

38. Mehlich, A. New extractant for soil test evaluation of phosphorus, potassium, magnesium, calcium, sodium, manganese and zinc. Commun. Soil Sci. Plant Anal. 1978, 9, 477-492. [CrossRef]

39. Calazans, S.O.L.; Morais, V.A.; Scolforo, J.R.S.; Zinn, Y.L.; Mello, J.M.; Mancini, L.T.; Silva, C.A. Soil organic carbon as a key predictor of $\mathrm{N}$ in forest soils of Brazil. J. Soils Sediments 2018, 18, 1242-1251. [CrossRef]

40. Asaf, S.; Khan, A.L.; Khan, M.A.; Imran, Q.M.; Yun, B.-W.; Lee, I.-J. Osmoprotective functions conferred to soybean plants via inoculation with Sphingomonas sp. LK11 and exogenous trehalose. Microbiol. Res. 2017, 205, 135-145. [CrossRef] [PubMed]

41. Asaf, S.; Khan, M.A.; Khan, A.L.; Waqas, M.; Shahzad, R.; Kim, A.-Y.; Kang, S.-M.; Lee, I.-J. Bacterial endophytes from arid land plants regulate endogenous hormone content and promote growth in crop plants: An example of Sphingomonas sp. and Serratia marcescens. J. Plant Interact. 2017, 12, 31-38. [CrossRef]

42. Khan, M.A.; Asaf, S.; Khan, A.L.; Adhikari, A.; Jan, R.; Ali, S.; Imran, M.; Kim, K.M.; Lee, I.J. Plant growth-promoting endophytic bacteria augment growth and salinity tolerance in rice plants. Plant Biol. 2020, 22, 850-862. [CrossRef]

43. Khan, M.A.; Asaf, S.; Khan, A.L.; Adhikari, A.; Jan, R.; Ali, S.; Imran, M.; Kim, K.-M.; Lee, I.-J. Halotolerant Rhizobacterial Strains Mitigate the Adverse Effects of $\mathrm{NaCl}$ Stress in Soybean Seedlings. BioMed Res. Int. 2019, 2019, 1-5. [CrossRef]

44. Khan, M.A.; Asaf, S.; Khan, A.L.; Jan, R.; Kang, S.-M.; Kim, K.-M.; Lee, I.-J. Rhizobacteria AK1 remediates the toxic effects of salinity stress via regulation of endogenous phytohormones and gene expression in soybean. Biochem. J. 2019, 476, 2393-2409. [CrossRef] [PubMed]

45. Sahile, A.A.; Khan, M.A.; Hamayun, M.; Imran, M.; Kang, S.-M.; Lee, I.-J. Novel Bacillus cereus Strain, ALT1, Enhance Growth and Strengthens the Antioxidant System of Soybean under Cadmium Stress. Agronomy 2021, 11, 404. [CrossRef]

46. Naga Raju, M.; Golla, N.; Vengatampalli, R. Soil Physicochemical Properties. In Soil Enzymes: Influence of Sugar Industry Effluents on Soil Enzyme Activities; Maddela, N.R., Golla, N., Vengatampalli, R., Eds.; Springer International Publishing: Cham, Switzerland, 2017; pp. 5-10. [CrossRef]

47. Fomenky, N.N.; Tening, A.S.; Chuyong, G.B.; Mbene, K.; Asongwe, G.A.; Che, V.B. Selected physicochemical properties and quality of soils around some rivers of Cameroon. J. Soil Sci. Environ. Manag. 2018, 9, 68-80.

48. Neina, D. The role of soil pH in plant nutrition and soil remediation. Appl. Environ. Soil Sci. 2019, 2019, 1-9. [CrossRef] 
49. Dixon, J.B.; Schulze, D.G. Soil Mineralogy with Environmental Applications; Soil Science Society of America Inc.: Madison, WI, USA, 2002.

50. Brevik, E.C.; Fenton, T.E.; Lazari, A. Soil electrical conductivity as a function of soil water content and implications for soil mapping. Precis. Agric. 2006, 7, 393-404. [CrossRef]

51. Quinton, J.N.; Govers, G.; Van Oost, K.; Bardgett, R.D. The impact of agricultural soil erosion on biogeochemical cycling. Nat. Geosci. 2010, 3, 311-314. [CrossRef]

52. Li, J.; Nie, M.; Powell, J.R.; Bissett, A.; Pendall, E. Soil physico-chemical properties are critical for predicting carbon storage and nutrient availability across Australia. Environ. Res. Lett. 2020, 15, 094088. [CrossRef]

53. Uchida, R. Essential nutrients for plant growth: Nutrient functions and deficiency symptoms. Plant Nutr. Manag. Hawaii's Soils 2000, 4, 31-55.

54. Lee, E.-P.; Han, Y.-S.; Lee, S.-I.; Cho, K.-T.; Park, J.-H.; You, Y.-H. Effect of nutrient and moisture on the growth and reproduction of Epilobium hirsutum L., an endangered plant. J. Ecol. Environ. 2017, 41, 35. [CrossRef]

55. Sharma, P.; Gaur, V.K.; Sirohi, R.; Varjani, S.; Kim, S.H.; Wong, J.W. Sustainable processing of food waste for production of bio-based products for circular bioeconomy. Bioresour. Technol. 2021, 325, 124684. [CrossRef]

56. Khan, M.A.; Sahile, A.A.; Jan, R.; Asaf, S.; Hamayun, M.; Imran, M.; Adhikari, A.; Kang, S.-M.; Kim, K.-M.; Lee, I.-J. Halotolerant bacteria mitigate the effects of salinity stress on soybean growth by regulating secondary metabolites and molecular responses. BMC Plant Biol. 2021, 21, 1-15. [CrossRef] [PubMed]

57. Golwala, H.; Zhang, X.; Iskander, S.M.; Smith, A.L. Solid waste: An overlooked source of microplastics to the environment. Sci. Total. Environ. 2021, 769, 144581. [CrossRef]

58. Adhikari, A.; Khan, M.A.; Lee, K.E.; Kang, S.M.; Dhungana, S.K.; Bhusal, N.; Lee, I.J. The Halotolerant RhizobacteriumPseudomonas koreensis MU2 Enhances Inorganic Silicon and Phosphorus Use Efficiency and Augments Salt Stress Tolerance in Soybean (Glycine max L.). Microorganisms 2020, 8, 1256. [CrossRef]

59. Khan, M.A.; Asaf, S.; Khan, A.L.; Jan, R.; Kang, S.-M.; Kim, K.-M.; Lee, I.-J. Thermotolerance effect of plant growth-promoting Bacillus cereus SA1 on soybean during heat stress. BMC Microbiol. 2020, 20, 175. [CrossRef] [PubMed]

60. Khan, M.A.; Asaf, S.; Khan, A.L.; Jan, R.; Kang, S.-M.; Kim, K.-M.; Lee, I.-J. Extending thermotolerance to tomato seedlings by inoculation with SA1 isolate of Bacillus cereus and comparison with exogenous humic acid application. PLoS ONE 2020, 15, e0232228. [CrossRef]

61. Kubi, H.A.A.; Khan, M.A.; Adhikari, A.; Imran, M.; Kang, S.-M.; Hamayun, M.; Lee, I.-J. Silicon and Plant Growth-Promoting Rhizobacteria Pseudomonas psychrotolerans CS51 Mitigates Salt Stress in Zea mays L. Agriculture 2021, 11, 272. [CrossRef]

62. Asaf, S.; Hamayun, M.; Khan, A.L.; Waqas, M.; Khan, M.A.; Jan, R.; Lee, I.J.; Hussain, A. Salt tolerance of Glycine max L. induced by endophytic fungus Aspergillus flavus CSH1, via regulating its endogenous hormones and antioxidative system. Plant Physiol. Biochem. 2018, 128, 13-23. [CrossRef] [PubMed]

63. Khan, M.A.; Hamayun, M.; Asaf, S.; Khan, M.; Yun, B.-W.; Kang, S.-M.; Lee, I.-J. Rhizospheric Bacillus spp. Rescues Plant Growth Under Salinity Stress via Regulating Gene Expression, Endogenous Hormones, and Antioxidant System of Oryza sativa L. Front. Plant Sci. 2021, 12. [CrossRef] [PubMed]

64. Woldemariam, S.H.; Lal, S.; Zelelew, D.Z.; Solomon, M.T. Effect of Potassium Levels on Productivity and Fruit Quality of Tomato (Lycopersicon esculentum L.). J. Agric. Stud. 2018, 6, 104-117. [CrossRef]

65. Zhang, J.; Li, B.; Zhang, J.; Christie, P.; Li, X. Organic fertilizer application and Mg fertilizer promote banana yield and quality in an Udic Ferralsol. PLoS ONE 2020, 15, e0230593. [CrossRef]

66. Maathuis, F.J.M. Physiological functions of mineral macronutrients. Curr. Opin. Plant Biol. 2009, 12, 250-258. [CrossRef]

67. Nabel, M.; Schrey, S.D.; Poorter, H.; Koller, R.; Jablonowski, N.D. Effects of digestate fertilization on Sida hermaphrodita: Boosting biomass yields on marginal soils by increasing soil fertility. Biomass Bioenergy 2017, 107, 207-213. [CrossRef]

68. Mu, D.; Hawks, J.; Diaz, A. Impacts on vegetable yields, nutrient contents and soil fertility in a community garden with different compost amendments. AIMS Environ. Sci. 2020, 7, 350-365. [CrossRef]

69. Dlamini, M.V.; Mukabwe, W.O.; Sibandze, N.N. The effects of organic liquid fertilizer (Vegetable waste) on moisture retention, soil physical properties and yield of lettuce (Lactuca sativa L.) Grown in the malkerns area, a region in the kingdom of eswatini. Adv. Agric. Hortic. Entomol. 2020, 1-6. [CrossRef] 